\title{
Relationship between Career Success Perception and Protean Career Management Behavior in Clinical Dental Hygienists
}

\author{
Soo-Auk Park ${ }^{\dagger}$ and Young-Sik Cho \\ Department of Dental Hygiene, Namseoul University, Cheonan 31020, Korea
}

\begin{abstract}
Background: Career success is the psychological achievement associated with an individual's work. Protean career management behavior is the behavior of managing individual careers in order to achieve individual career goals. The purpose of this study was to clarify the career success of dental hygienists as perceived by clinical dental hygienists and to compare the relationship between career success and protean career management behavior.

Methods: Nationwide convenience samples of clinical dental hygienists were obtained; 354 people were surveyed online, and the data of 350 people were finally analyzed. The perception of career success of dental hygienists was assessed using a multiple response method. T-test, ANOVA, and $\chi^{2}$ tests were performed to investigate the differences and relationships between protean career management behavior and career success according to the general characteristics.

Results: Career success was recognized by clinical dental hygienists as "income", "work proficiency", "patient consultation", "self-satisfaction", and "recognition by superiors" in order. There were significant differences in protean career management behavior according to general characteristics $(p<0.05)$. Higher career management behavior was common in those higher in age, in married participants, in those with higher educational background, and in those with a higher career, better position, and more job change experience $(p<0.05)$. Among the variables of career success perceived by clinical dental hygienists, "work proficiency" had a significant effect on "career management behavior" $(p<0.05)$. "Work proficiency" and "recognition by superiors" were significant in "protean technological development behavior," and they also influenced actual behavior $(p<0.05)$. Conclusion: The relationship between dental hygienists' career success and protean career management behavior was clarified. Dental hygienists performed career management behaviors to develop work ability and skills. In addition, the relationship between career management behavior and long-term employment was confirmed.
\end{abstract}

Key Words: Career, Career management, Career success, Dental hygienist, Protean career management behavior

\section{Introduction}

The term "career" refers to the process of all objective and subjective experiences acquired by an individual in relation to work throughout his or her lifetime ${ }^{1)}$. Promotions and wage increases were considered important in the past. However, recently, it has become an era in which individuals become the focus, manage their own careers, and take responsibility ${ }^{2)}$.

In career-related studies, 'career success' is studied extensively as a construct. Career success considers an individual's positive mental state and work-related achievements gained through work experience ${ }^{1)}$. It can be used to judge the efficiency of individual career development ${ }^{3)}$. Research on career success has been carried out in two dimensions: objective and subjective career success ${ }^{4,5}$. Objective career success refers to career achievements that can be measured with an observable objective indicator ${ }^{6)}$, and it is mainly measured by income and the number of promotions ${ }^{7)}$. Subjective career success judges career 
success through the self-subjective evaluation of one's career and a sense of accomplishment ${ }^{8}$. Organizational members in modern society tend to regard subjective career success with more importance than objective career success $^{9-11)}$.

In traditional careers, the organization was the responsibility of the management, and it is mainly aimed at promotions or salary increases, but the protean career is primarily individual and aims to improve psychological success $^{12}$. Protean career management behavior is an individual-led career management behavior that aims to achieve career goals set by an individual from a protean career perspective $^{2)}$. Protean is a concept derived from the god Proteus in Greek mythology. Protean means that something changes according to one's will depending on changes in the environment. This is because careers also change based on the wishes of individuals ${ }^{13}$. Protean career management behavior comprises protean career planning behavior, protean networking behavior, and protean technological development behavior ${ }^{2}$. Protean career planning behavior is an action that sets one's career goals aiming for psychological success, considering individual growth and freedom as core values. Protean networking behavior is an action that seeks advice and establishes a relationship that is helpful for personal career growth through various interpersonal relationships based on an individual's psychological success. Lastly, protean technological development behavior is an action that strives to acquire knowledge and skills for long-term career management for individual psychological success ${ }^{2}$.

Prior studies on the relationship between career success and career management behavior have reported that protean career management behavior had a direct influence on subjective career success ${ }^{2}$. Career management behavior was positively associated with personal career satisfaction, career commitment, and career success ${ }^{14,15}$. This suggests that career management behavior is an important variable for career success. Domestic research on career success began in earnest in the 2000s and is on the rise ${ }^{16,17)}$.

However, in the field of healthcare, research on career success is insufficient. In particular, career management behavior and career success in domestic and foreign health fields have not been studied yet. The career perspective is changing, and research on career success is actively being conducted. In the field of dental hygiene, it is necessary to conduct research on careers. Career success can be seen as the final goal of a professional dental hygienist.

Therefore, this study aimed to investigate the career success of dental hygienists as recognized by clinical dental hygienists and to confirm the relationship of career success with career management behavior. Based on the results, I would like to discuss the academic and practical implications of career success and career management behavior from the viewpoint of lack of human resources in health care.

\section{Materials and Methods}

\section{Subjects and methods}

This study was conducted online from March 12, 2020, to June 1,2020 , using a convenience sample extraction method in clinical dental hygienists working at dental clinics or hospitals nationwide. The sample size analyzed using the $G^{*}$ power 3.1.9.4 program was 172 , but the questionnaire was distributed to a total of 354 people, considering the dropout rate. Data of 350 people were used for the final analysis, after excluding 4 people who were judged to have missed some of the survey contents or because they responded unfaithfully. This study was conducted using the online survey, for which a questionnaire was created in Korean language using the 'Naver form' with exemption of informed consent from the IRB review.

\section{Questionnaire}

\section{1) General characteristics}

There were totally 7 questions on general characteristics, including individual characteristics like age, sex, marital status, and education. Work career characteristics comprised total working years, position, and turnover.

\section{2) Career success}

The study employed a semi-structured questionnaire comprising 18 questions that could consider the professional success of a dental hygienist. The answers were selected 
from multiple responses. Data were collected on income, total career, position, patient consultation, relationship with patients, relationship with colleagues, relationship with superiors, reflection of opinion of the institution, work proficiency, promotion, number of days off, support at the dental clinic, recognition by superiors, employment in public institution, self-satisfaction, external lectures, incentives, and others. There were 18 multiple response items.

\section{3) Protean career management behavior}

Measurements were made using Shin and Jeong's tool ${ }^{2}$. Protean career management behavior scale (Cronbach's $\alpha=0.885$ ) comprised 12 questions consisting of three sub-factors. Protean career planning behavior consisted of four questions (Cronbach's $\alpha=0.822$ ) seeking data regarding the question, "I am constantly recording and managing my current performance." Protean networking behavior consisted of four questions (Cronbach's $\alpha=0.882$ ) seeking data regarding the question, "I am actively contacting people who can influence my career first." Protean technological development behavior consists of

Table 1. Perception of Career Success as a Clinical Dental Hygienist $(n=350)$

\begin{tabular}{clrc}
\hline Rank & \multicolumn{1}{c}{ Career success factor $^{\mathrm{a}}$} & Sum (n) & $\%$ \\
\hline 1 & Income & 311 & 88.86 \\
2 & Work proficiency & 243 & 69.43 \\
3 & Patient consultation & 188 & 53.71 \\
4 & Self-satisfaction & 174 & 49.71 \\
5 & Recognition by superiors & 166 & 47.43 \\
6 & Position & 131 & 37.43 \\
7 & Reflection of opinion & 125 & 35.71 \\
8 & Relationship with colleagues & 114 & 32.57 \\
8 & Incentive & 114 & 32.57 \\
10 & Relationship with superiors & 108 & 30.86 \\
11 & Relationship with the patient & 89 & 25.43 \\
12 & Number of days off & 86 & 24.57 \\
13 & Support at the dental clinic & 75 & 21.43 \\
14 & Total career & 73 & 20.86 \\
15 & Employment in public institution & 43 & 12.29 \\
16 & External lecture & 38 & 10.86 \\
17 & Promotion & 37 & 10.57 \\
18 & Others & 4 & 1.14 \\
\hline
\end{tabular}

${ }^{\mathrm{a}}$ Multiple responses.

${ }^{b}$ Dental hygienist job reputation. four questions (Cronbach's $\alpha=0.789$ ) seeking data regarding the question, "I am striving for self-development in addition to the mandatory education of the hospital."

Each question was answered on a 5-point Likert scale, and it was judged that the higher the score, the higher the degree of career management behavior. In this study, Cronbach's $\alpha$ for 'protean career management behavior' was 0.844; 'protean career planning behavior', 0.688; 'protean networking behavior', 0.782; and, 'protean technological development behavior', 0.767 .

\section{Data analysis}

A descriptive statistical analysis was conducted on the general characteristics of the study subjects. A multiresponse analysis was performed on career success perception. The $\chi^{2}$ test was conducted to determine the relationship between the general characteristics of the study subjects and career success perception. Independent two-sample t-tests and one-way ANOVA were performed to determine the differences in protean career management behavior according to the general characteristics. Post-analysis was performed using Scheffe's multiple comparison test. An independent two-sample t-test was performed to investigate the differences in protean career management behavior according to career success perception.

Table 2. Dental Hygienists who did not Choose Income $(n=39)$

\begin{tabular}{clcc}
\hline Rank & \multicolumn{1}{c}{ Career success factor $^{\mathrm{a}}$} & Sum (n) & $\%$ \\
\hline 1 & Work proficiency & 23 & 58.97 \\
2 & Patient consultation & 16 & 41.03 \\
3 & Relationship with superiors & 14 & 35.90 \\
4 & Relationship with colleagues & 13 & 33.33 \\
4 & Reflection of opinion & 13 & 33.33 \\
4 & Self-satisfaction & 13 & 33.33 \\
7 & Relationship with the patient & 12 & 30.77 \\
7 & Recognition by superiors & 12 & 30.77 \\
9 & Position & 9 & 23.08 \\
10 & Employment in public institution & 7 & 17.95 \\
11 & Total career & 5 & 12.82 \\
11 & External lecture & 5 & 12.82 \\
13 & Incentive & 4 & 10.26 \\
14 & Promotion & 3 & 7.69 \\
15 & Number of days off & 2 & 5.13 \\
15 & Support at the dental clinic & 2 & 5.13 \\
\hline
\end{tabular}

${ }^{\mathrm{a}}$ Multiple responses. 
The collected data were analyzed using the PASW Statistics version 18.0 (IBM Corp., Armonk, NY, USA) program.

\section{Results}

\section{Perception of career success as a clinical dental hygienist}

Table 1 shows the perception of career success as a clinical dental hygienist. More than $50 \%$ of respondents perceived income $(88.86 \%)$, work proficiency $(69.43 \%)$, and patient consultation $(53.71 \%)$ as measures of career success. Most of the respondents perceived income to be important (Table 1).

In contrast, 39 dental hygienists did not perceive income to be a measure of career success (Table 2). The criteria for success in their careers were work proficiency $(58.97 \%)$, patient consultation $(41.03 \%)$, and relationship with superiors $(35.90 \%)$.

\section{The relationship between general characteristics of dental hygienists and career success perception}

\section{1) The relationship between individual characteristics and career success perception}

Cross-analyses (chi-square test) were performed to determine the relationship between the top five career success perceptions ( $40 \%$ or more), and the individual characteristics in the career success perception are presented in Table 1 (Table 3).

Marriage and income were related $\left(\chi^{2}=5.021, \mathrm{p}=0.025\right)$. In particular, the unmarried group considered income to be more important in career success than the married group. Final graduates had a statistically significant difference in patient consultation $\left(\chi^{2}=6.453, \mathrm{p}=0.011\right)$. In particular, in the college-going group, patient consultation was selected as important for career success.

\section{2) The relationship between work career} characteristics and career success perception

In Table 1, the relationships between the top five career success perceptions (more than 40\%) and work career characteristics were compared (Table 4). There was a

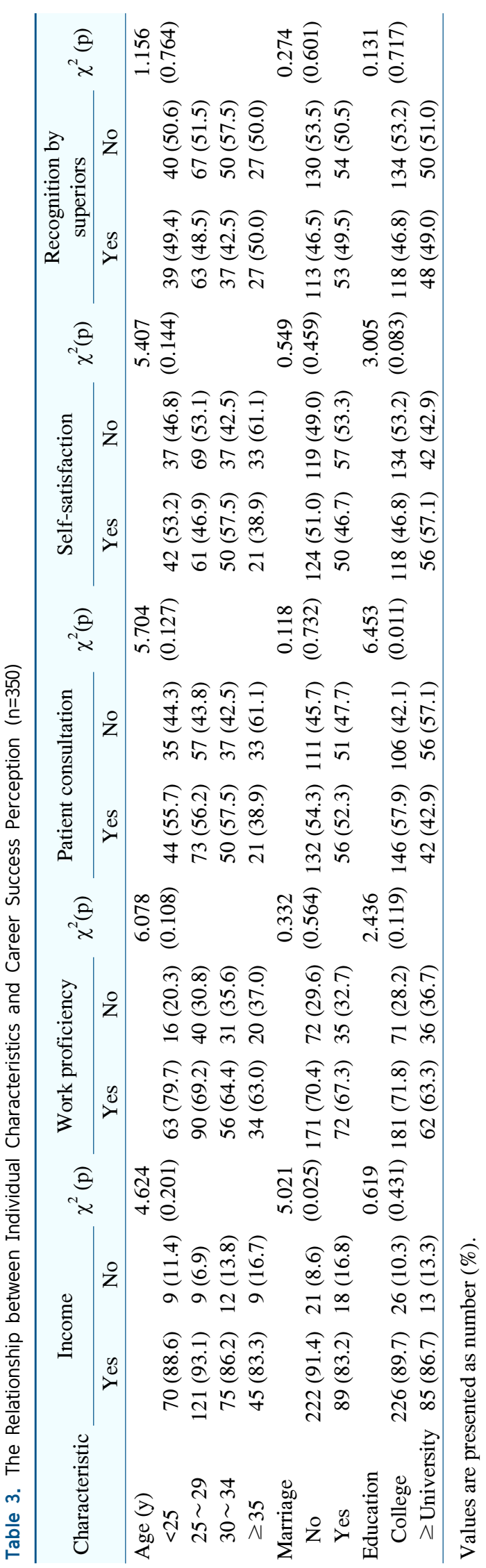




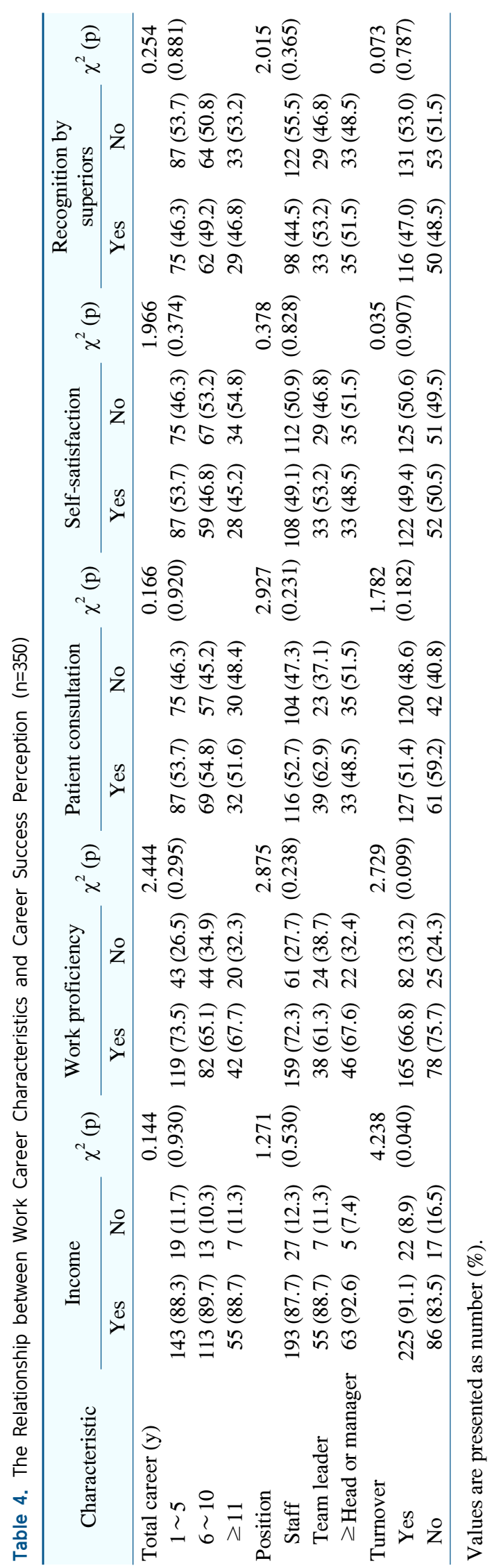

statistically significant difference between turnover and income $\left(\chi^{2}=4.238, p=0.040\right)$. In particular, the group that had experienced turnover chose income to be important in career success.

\section{Differences in protean career management behavior according to the general characteristics of dental hygienists}

\section{1) Differences in protean career management}

\section{behavior according to individual characteristics}

Table 5 shows the differences in protean career management behavior according to individual characteristics. The distribution of participants according to age was $25 \sim$ 29 years, 37.1\%; 30 34 years, $24.9 \%$; under 25 years, $22.6 \%$; and, 35 years or older, $15.4 \%$. There were many unmarried (69.4\%) and college-going (72.0\%) dental hygienists. All the participants were female.

Protean career management behavior and the subfactors according to individual characteristics were all statistically significant $(\mathrm{p}<0.05)$. Career management behavior according to age showed a significant difference between the 30 s or older group and the under-25 group $(\mathrm{p}<0.001)$. The married group $(\mathrm{p}=0.001)$ and the university or higher group $(\mathrm{p}<0.001)$ were more highly involved in protean career management behavior. Regarding the sub-factors of protean career management behavior, it was found that increased age, higher education level, and being married showed more career planning, networking, and technical development behaviors $(\mathrm{p}<$ $0.05)$.

\section{2) Differences in protean career management} behavior according to work career characteristics

Table 6 shows the differences in protean career management behavior according to work career characteristics. The distribution of subjects as per total working years was $1 \sim 5$ years, $46.3 \%$; 6 10 years, $36.0 \%$; and, 11 years or more, $17.7 \%$. Most of the subjects were staff members $(62.9 \%)$, and there were many groups who experienced turnovers (70.6\%).

Protean career management behavior and sub-factors according to work career characteristics were all statistically 
Table 5. Differences in Protean Career Management Behavior according to Individual Characteristics ( $n=350)$

\begin{tabular}{|c|c|c|c|c|c|c|c|c|c|c|}
\hline \multirow[t]{2}{*}{ Characteristic } & \multirow[t]{2}{*}{ Classification } & \multirow[t]{2}{*}{$\mathrm{n}(\%)$} & \multicolumn{2}{|c|}{ Career management } & \multicolumn{2}{|c|}{ Career planning } & \multicolumn{2}{|c|}{ Networking } & \multicolumn{2}{|c|}{$\begin{array}{c}\text { Technological } \\
\text { development }\end{array}$} \\
\hline & & & Mean \pm SD & $\mathrm{t} / \mathrm{F}(\mathrm{p})$ & Mean \pm SD & $\mathrm{t} / \mathrm{F}(\mathrm{p})$ & Mean \pm SD & $\mathrm{t} / \mathrm{F}(\mathrm{p})$ & Mean \pm SD & $\mathrm{t} / \mathrm{F}(\mathrm{p})$ \\
\hline \multirow[t]{4}{*}{ Age (y) } & $<25$ & $79(22.6)$ & $2.81 \pm 0.62^{\mathrm{a}}$ & \multirow[t]{4}{*}{$<0.001$} & $3.20 \pm 0.73^{\mathrm{a}}$ & \multirow{4}{*}{0.001} & $2.93 \pm 0.85^{\mathrm{a}}$ & \multirow[t]{4}{*}{0.009} & $2.52 \pm 0.86^{\mathrm{a}}$ & \multirow[t]{4}{*}{$<0.001$} \\
\hline & $25 \sim 29$ & $130(37.1)$ & $3.02 \pm 0.64^{\mathrm{ab}}$ & & $3.30 \pm 0.73^{\mathrm{ab}}$ & & $3.13 \pm 0.89^{\mathrm{ab}}$ & & $2.80 \pm 0.78^{\mathrm{ab}}$ & \\
\hline & $30 \sim 34$ & 87 (24.9) & $3.26 \pm 0.66^{\mathrm{bc}}$ & & $3.59 \pm 0.72^{\mathrm{b}}$ & & $3.18 \pm 0.89^{\mathrm{ab}}$ & & $3.14 \pm 0.91^{\mathrm{bc}}$ & \\
\hline & $\geq 35$ & $54(15.4)$ & $3.36 \pm 0.66^{c}$ & & $3.54 \pm 0.73^{\mathrm{b}}$ & & $3.46 \pm 0.91^{\mathrm{b}}$ & & $3.19 \pm 0.81^{\mathrm{c}}$ & \\
\hline \multirow[t]{2}{*}{ Marriage } & No & $243(69.4)$ & $3.00 \pm 0.65$ & \multirow[t]{2}{*}{0.001} & $3.31 \pm 0.75$ & 0.005 & $3.06 \pm 0.85$ & \multirow[t]{2}{*}{0.005} & $2.81 \pm 0.86$ & \multirow[t]{2}{*}{0.020} \\
\hline & Yes & $107(30.6)$ & $3.26 \pm 0.67$ & & $3.56 \pm 0.70$ & & $3.35 \pm 0.95$ & & $3.04 \pm 0.88$ & \\
\hline \multirow[t]{2}{*}{ Education } & College & $252(72.0)$ & $2.96 \pm 0.64$ & \multirow[t]{2}{*}{$<0.001$} & $3.33 \pm 0.74$ & 0.029 & $3.03 \pm 0.90$ & \multirow[t]{2}{*}{$<0.001$} & $2.72 \pm 0.84$ & \multirow[t]{2}{*}{$<0.001$} \\
\hline & $\geq$ University & $98(28.0)$ & $3.40 \pm 0.63$ & & $3.53 \pm 0.73$ & & $3.46 \pm 0.80$ & & $3.29 \pm 0.82$ & \\
\hline
\end{tabular}

SD: standard deviation.

${ }^{\mathrm{a} \sim \mathrm{c}}$ The same letter indicates no significant difference at $\alpha=0.05$ by Scheffe multiple comparison test.

Table 6. Differences in Protean Career Management Behavior according to Work Career Characteristics $(n=350)$

\begin{tabular}{|c|c|c|c|c|c|c|c|c|c|c|}
\hline \multirow[t]{2}{*}{ Characteristic } & \multirow[t]{2}{*}{ Classification } & \multirow[t]{2}{*}{$\mathrm{n}(\%)$} & \multicolumn{2}{|c|}{ Career management } & \multicolumn{2}{|c|}{ Career planning } & \multicolumn{2}{|c|}{ Networking } & \multicolumn{2}{|c|}{$\begin{array}{c}\text { Technological } \\
\text { development }\end{array}$} \\
\hline & & & Mean \pm SD & $\mathrm{t} / \mathrm{F}(\mathrm{p})$ & Mean \pm SD & $\mathrm{t} / \mathrm{F}(\mathrm{p})$ & Mean \pm SD & $\mathrm{t} / \mathrm{F}(\mathrm{p})$ & Mean \pm SD & $\mathrm{t} / \mathrm{F}(\mathrm{p})$ \\
\hline \multirow[t]{3}{*}{ Total career $(\mathrm{y})$} & $1 \sim 5$ & $162(46.3)$ & $2.95 \pm 0.61^{\mathrm{a}}$ & $<0.001$ & $3.28 \pm 0.70^{\mathrm{a}}$ & 0.016 & $3.03 \pm 0.83^{\mathrm{a}}$ & 0.040 & $2.73 \pm 0.83^{\mathrm{a}}$ & 0.002 \\
\hline & $6 \sim 10$ & $126(36.0)$ & $3.13 \pm 0.68^{\mathrm{ab}}$ & & $3.42 \pm 0.76^{\mathrm{ab}}$ & & $3.21 \pm 0.91^{\mathrm{ab}}$ & & $2.93 \pm 0.87^{\mathrm{ab}}$ & \\
\hline & $\geq 11$ & $62(17.7)$ & $3.33 \pm 0.71^{\mathrm{b}}$ & & $3.59 \pm 0.78^{\mathrm{b}}$ & & $3.34 \pm 0.97^{\mathrm{b}}$ & & $3.18 \pm 0.92^{\mathrm{b}}$ & \\
\hline \multirow[t]{3}{*}{ Position } & Staff & $220(62.9)$ & $2.94 \pm 0.61^{\mathrm{a}}$ & $<0.001$ & $3.28 \pm 0.72^{\mathrm{a}}$ & $<0.001$ & $3.03 \pm 0.88^{\mathrm{a}}$ & $<0.001$ & $2.71 \pm 0.81^{\mathrm{a}}$ & $<0.001$ \\
\hline & Team leader & $62(17.7)$ & $3.14 \pm 0.70^{\mathrm{a}}$ & & $3.48 \pm 0.78^{\mathrm{ab}}$ & & $3.13 \pm 0.91^{\mathrm{a}}$ & & $2.98 \pm 0.86^{\mathrm{a}}$ & \\
\hline & $\begin{array}{c}\geq \text { Head or } \\
\text { manager }\end{array}$ & $68(19.4)$ & $3.48 \pm 0.66^{\mathrm{b}}$ & & $3.67 \pm 0.71^{\mathrm{b}}$ & & $3.54 \pm 0.82^{\mathrm{b}}$ & & $3.34 \pm 0.89^{\mathrm{b}}$ & \\
\hline \multirow[t]{2}{*}{ Turnover } & Yes & 247 (70.6) & $3.18 \pm 0.67$ & $<0.001$ & $3.44 \pm 0.77$ & 0.028 & $3.24 \pm 0.91$ & 0.002 & $3.01 \pm 0.86$ & $<0.001$ \\
\hline & No & $103(29.4)$ & $2.85 \pm 0.62$ & & $3.25 \pm 0.65$ & & $2.93 \pm 0.82$ & & $2.58 \pm 0.82$ & \\
\hline
\end{tabular}

SD: standard deviation.

${ }^{\mathrm{a}, \mathrm{b}}$ The same letter indicates no significant difference at $\alpha=0.05$ by Scheffe multiple comparison test.

significant $(\mathrm{p}<0.05)$. Protean career management behavior was seen in those with higher career $(p<0.001)$, higher position $(\mathrm{p}<0.001)$, and those with turnover experience $(\mathrm{p}<0.001)$. There was a significant difference in total working years in the 11 years or older group and the $1 \sim 5$ years group $(p<0.001)$. In terms of position, except for protean career planning behavior, there was a significant difference between the head or manager or higher group and the team leader or lower group $(\mathrm{p}<0.001)$. In protean career planning behavior, there was a significant difference between the head or manager or above group and the staff group $(\mathrm{p}<0.001)$.

\section{Differences in protean career management behavior according to dental hygienist's career success perception}

The top five ( $40 \%$ or more) career success perceptions presented in Table 1 were used as independent variables (Table 7). This study investigated the difference between the career success perceived by dental hygienists and actual protean career management behavior. Among the expected career success perceptions, only work proficiency had a significant effect on protean career management behavior $(p=0.006)$. Work proficiency was statistically significant in protean networking behavior and protean technological development behavior, after excluding protean career planning behavior as a sub-factor $(\mathrm{p}<$ 0.05 ). Recognition by superiors had a significant effect 
Table 7. Differences in Protean Career Management Behavior according to Dental Hygienist's Career Success Perception ( $n=350$ )

\begin{tabular}{|c|c|c|c|c|c|c|c|c|c|c|}
\hline \multicolumn{2}{|c|}{ Characteristic } & \multirow[t]{2}{*}{$\mathrm{n}(\%)$} & \multicolumn{2}{|c|}{ Career management } & \multicolumn{2}{|c|}{ Career planning } & \multicolumn{2}{|c|}{ Networking } & \multicolumn{2}{|c|}{$\begin{array}{c}\text { Technological } \\
\text { development }\end{array}$} \\
\hline & & & Mean \pm SD & $\mathrm{t}(\mathrm{p})$ & Mean \pm SD & $\mathrm{t}(\mathrm{p})$ & Mean \pm SD & $\mathrm{t}(\mathrm{p})$ & Mean \pm SD & $\mathrm{t}(\mathrm{p})$ \\
\hline \multirow[t]{2}{*}{ Income } & Yes & $311(88.9)$ & $3.14 \pm 0.70$ & 0.554 & $3.45 \pm 0.77$ & 0.583 & $3.16 \pm 0.90$ & 0.595 & $3.04 \pm 0.93$ & 0.231 \\
\hline & No & 39 (11.1) & $3.08 \pm 0.67$ & & $3.38 \pm 0.74$ & & $3.08 \pm 0.86$ & & $2.86 \pm 0.86$ & \\
\hline \multirow{2}{*}{$\begin{array}{l}\text { Work } \\
\text { proficiency }\end{array}$} & Yes & $243(69.4)$ & $3.23 \pm 0.65$ & 0.006 & $3.40 \pm 0.71$ & 0.540 & $3.31 \pm 0.81$ & 0.016 & $3.11 \pm 0.85$ & 0.001 \\
\hline & No & $107(30.6)$ & $3.02 \pm 0.67$ & & $3.35 \pm 0.80$ & & $3.08 \pm 0.92$ & & $2.78 \pm 0.87$ & \\
\hline \multirow{2}{*}{$\begin{array}{l}\text { Patient } \\
\text { consultation }\end{array}$} & Yes & $188(53.7)$ & $3.12 \pm 0.67$ & 0.289 & $3.40 \pm 0.76$ & 0.797 & $3.18 \pm 0.86$ & 0.502 & $2.94 \pm 0.88$ & 0.228 \\
\hline & No & $162(46.3)$ & $3.05 \pm 0.67$ & & $3.38 \pm 0.73$ & & $3.12 \pm 0.92$ & & $2.83 \pm 0.87$ & \\
\hline \multirow[t]{2}{*}{ Self-satisfaction } & Yes & $174(49.7)$ & $3.10 \pm 0.68$ & 0.720 & $3.44 \pm 0.70$ & 0.214 & $3.23 \pm 0.88$ & 0.075 & $2.89 \pm 0.87$ & 0.830 \\
\hline & No & $176(50.3)$ & $3.07 \pm 0.65$ & & $3.34 \pm 0.78$ & & $3.06 \pm 0.90$ & & $2.87 \pm 0.88$ & \\
\hline \multirow{2}{*}{$\begin{array}{l}\text { Recognition by } \\
\text { superiors }\end{array}$} & Yes & $166(47.4)$ & $3.14 \pm 0.66$ & 0.077 & $3.42 \pm 0.74$ & 0.448 & $3.15 \pm 0.92$ & $>0.999$ & $3.00 \pm 0.90$ & 0.006 \\
\hline & No & $184(52.6)$ & $3.02 \pm 0.67$ & & $3.36 \pm 0.75$ & & $3.15 \pm 0.87$ & & $2.75 \pm 0.83$ & \\
\hline
\end{tabular}

SD: standard deviation.

only on protean technological development behavior $(\mathrm{p}=0.006)$.

\section{Discussion}

In the past, lifetime employment was guaranteed, but now, it is an era in which individuals manage their own careers and take responsibility ${ }^{2)}$. The career perspective is changing. Until now, most studies on the shortage of manpower in the dental hygiene field have focused on the organizational aspect. However, since this is an external factor, I conducted a study to solve the human resource problem through the internal psychology of dental hygienists. Therefore, this study investigated the career success of dental hygienists as recognized by clinical dental hygienists. In addition, I tried to investigate whether the dental hygienists actually managed their career for the expected career success.

First, the perception of success in the career of a dental hygienist was investigated (Table 1). In the end, a successful dental hygienist was perceived as one who received a large salary and worked well. Second, success was perceived as a high sense of self-esteem or self-efficacy, that is, psychological success. In contrast, relational elements such as interpersonal relationships were secondary. The position in an organization was of lower importance than expected, which seems to be because the position system of dental hygienists is not diverse or clear, and there are limitations to promotion.
From this result, the perception of success can be classified into three major categories; i.e., an external compensation aspect, an individual psychological aspect, and a relational aspect. Most dental hygienists considered income as a measure of career success. However, I attempted to identify what the group who did not choose income $(n=39)$ considered as career success (Table 2). This group considered individual psychological and relational aspects to be important (Table 2). Observably, objective career success was important, but subjective career success is also important.

I compared the high-level factors of career success and the general characteristics perceived by dental hygienists (Table 3, 4). Income, which most dental hygienists considered as a factor indicating the most success in their careers, was related to marriage and turnover. Marriage and income were related, and the unmarried group viewed income as a more important factor in career success than the married group. This seems to be because the unmarried group needed finances for marriage ${ }^{18)}$. In addition, they perceived income to be more important than the group who did not experience turnover in the turnover experience group. One of the reasons for the turnover of dental hygienists is income ${ }^{19)}$. The education was related to patient consultation. In particular, the college group chose patient consultation as a more important factor. This means that the time to learn liberal arts subjects, such as communication skills, in the curriculum of colleges, is relatively insufficient compared to that in the university ${ }^{20)}$. 
Therefore, it is judged that the level of education was a more important factor because of the relative lack of liberal arts competency.

The differences in protean career management behavior according to the general characteristics of dental hygienists were examined (Table 5, 6). In individual characteristics, it was found that as age increases, higher education level, and more career management behavior was observed in the married group $(\mathrm{p}<0.05)$ (Table 5). Age can be considered to be related to the total working years or position in work career characteristics. The married group performed more career management behavior than the unmarried group, which seems to be due to the sense of responsibility for the family. In contrast, in terms of work career characteristics, higher career, higher position, and those with turnover experience, showed more career management behavior $(p<0.05)$ (Table 6). It can be seen that one of the reasons of turnover in dental hygienists is career management ${ }^{21}$. In addition, a correlation can be observed between long-term employment and career management behavior. It is considered that they are able to manage their careers because they work for a long term. Alternatively, they can work for a long term because they manage their careers.

The relationship between the career success perceived by clinical dental hygienists and the actual protean career management behavior was confirmed (Table 7). Among career success perceptions, only work proficiency had a significant association with career management behavior $(\mathrm{p}<0.05)$. Work proficiency was significantly different from protean networking behavior and protean technological development behavior, after excluding protean career planning behavior $(\mathrm{p}<0.05)$. The job of a dental hygienist is relatively stable in terms of employment, suggesting that actual work is more important than career planning. In addition, among the career success perceptions, supervisor recognition also showed a significant difference in technology development behavior $(\mathrm{p}<0.05)$. Therefore, there was a common significant difference in work proficiency and supervisor recognition in technology development behavior $(p<0.05)$. This is because the profession of a dental hygienist is that of a professional medical technician; therefore, they aim for technology development ${ }^{22}$. Clinical dental hygienists perceived success in their careers when they were recognized for their unique work as dental hygienists and by being self-satisfied by their work proficiency.

However, although most dental hygienists are aware that career success factors are important, there is a difference from the actual practice of career management behavior. This is because dental hygienists do not have to manage their careers because it is easy to find employment owing to a shortage of dental medical personnel ${ }^{23)}$. As mentioned earlier, since it is related to long-term employment, career management behavior should be performed in order to retain the workforce. To this end, we need to identify a way to satisfy the factors of career success perceived by dental hygienists.

This study has several limitations. The perception of career success of dental hygienists did not differ according to the general characteristics or protean career management behavior. It is necessary to determine whether there really was no difference or whether the problem was with survey methods such as multiple responses. In the future, research comparing standardized criteria for career success will be required. In addition, it may be difficult to measure the career success of dental hygienists due to the limitations of position promotion, annual salary, and easy employment and turnover due to the professional characteristics of the research subject. There was no prior research on the same occupation, and there were limitations to comparing it with other occupations.

However, it is meaningful to attempt to apply the concept of career success to understand the final goal of a dental hygienist. In addition, in this study, the variables for career success perceived by dental hygienists were identified, and the variables that influenced protean career management behavior for career success were confirmed.

This study dealt with individual-centered career success. Although career success has a positive effect on not only individuals but also organizations ${ }^{24)}$, research on career success in dental hygiene is insufficient. In the field of dental hygiene, it is also necessary to provide information on the pursuit of individual career success and how organizations should manage their careers. In addition, based on the results of this study, it is necessary to more 
accurately grasp the causal relationship between the long-term employment of dental hygienists and protean career management behavior. In the future, various studies on long-term employment of dental hygienists are needed to deal with careers at the individual and organizational levels.

\section{Notes}

\section{Conflict of interest}

No potential conflict of interest relevant to this article was reported.

\section{Ethical approval}

This study was approved by the Namseoul University Bioethics Review Committee (IRB NSU- 201910-001).

\section{Author contributions}

Conceptualization: Soo-Auk Park and Young-Sik Cho. Data acquisition: Soo-Auk Park. Formal analysis: Soo-Auk Park. Supervision: Young-Sik Cho. Writingoriginal draft: Soo-Auk Park. Writing-review \& editing: Young-Sik Cho.

\section{ORCID}

Soo-Auk Park, https://orcid.org/0000-0002-0226-2325

Young-Sik Cho, https://orcid.org/0000-0002-5845-8538

\section{References}

1. Arthur MB, Khapova SN, Wilderom CPM: Career success in a boundaryless career world. J Organ Behav 26: 177-202, 2005. https://doi.org/10.1002/job.290

2. Shin SL, Jeong JC: The causal relationships among subjective career success, job security, organizational career management support, protean career attitude, and protean career management behavior of the workers in major industries, Korea. J Agric Educ Hum Res Dev 46: 183-213, 2014.

https://doi.org/10.23840/agehrd.2014.46.2.183

3. Seibert SE, Kraimer ML, Liden RC: A social capital theory of career success. Acad Manag J 44: 219-237, 2001. https://doi.org/10.5465/3069452

4. Heslin PA: Conceptualizing and evaluating career success. J Organ Behav 26: 113-136, 2005. https://doi.org/10.1002/job.270

5. Hall DT, Chandler DE: Psychological success: when the career is a calling. J Organ Behav 26: 155-176, 2005. https://doi.org/10.1002/job.301

6. Judge TA, Cable DM, Boudreau JW, Bretz Jr. RD: An empirical investigation of the predictors of executive career success. Pers Psychol 48: 485-519, 1995. https://doi.org/10.1111/j.1744-6570.1995.tb01767.x

7. Ng TWH, Eby LT, Sorensen KL, Feldman DC: Predictors of objective and subjective career success: a meta-analysis. Pers Psychol 58: 367-408, 2005. https://doi.org/10.1111/j.1744-6570.2005.00515.x

8. Yu SR, Bae EK, Lee MY: The mediating effects of self-leadership on relationship between protean career attitude and subjective career success in lifelong learning educators. $\mathbf{J}$ Vocat Educ 37: 85-104, 2018. https://doi.org/10.37210/jver.2018.37.6.85

9. Kim BS, Lee HS, Song YS: The mediating effects of career related continuous learning (CRCL) on the relations between protean career attitudes and subjective career success. J Vocat Educ 34: 25-50, 2015.

10. Lo Presti A, Pluviano S, Briscoe JP: Are freelancers a breed apart? The role of protean and boundaryless career attitudes in employability and career success. Hum Resour Manag J 28: 427-442, 2018. https://doi.org/10.1111/1748-8583.12188

11. Spurk D, Hirschi A, Dries N: Antecedents and outcomes of objective versus subjective career success: competing perspectives and future directions. J Manag 45: 35-69, 2019. https://doi.org/10.1177/0149206318786563

12. Hall DT: Careers in organizations. Goodyear, Santa Monica, pp.1-235, 1976.

13. Kim YJ, Kim BW: The trends and issues of research on the protean career. J Humanit Soc Sci 8: 143-158, 2017. https://doi.org/10.22143/HSS21.8.6.10

14. Seibert SE, Kraimer ML, Crant JM: What do proactive people do? A longitudinal model linking proactive personality and career success. Pers Psychol 54: 845-874, 2001. https://doi.org/10.1111/j.1744-6570.2001.tb00234.x

15. Eby LT, Butts M, Lockwood A: Predictors of success in the 
era of the boundaryless career. J Organ Behav 24: 689-708, 2003. https://doi.org/10.1002/job.214

16. Kim MK, Moon JS: Trends in career success research of Korea. Korean J Hum Resour Dev 21: 221-261, 2018.

https://doi.org/10.24991/KJHRD.2018.12.21.4.221

17. Choi MB, Cho DY, Lee YS: A meta-analysis on career success of corporate employees. J Corp Educ Talent Res 21: $1-22,2019$.

https://doi.org/10.46260/kslp.21.1.1

18. Yoo HJ, Hyun SM: The effects of economic resources on marriage-delaying. Korea J Popul Stud 33: 75-101, 2010.

19. Park SA, Lee JY: A literature review on measurement tools for dental hygienist turnover intention in Korea. J Korean Soc Dent Hyg 19: 1-17, 2019. https://doi.org/10.13065/jksdh.20190001

20. Choi YK: NCS vocational basic ability improvement through college general curriculum. Korean J Gen Educ 11: 525-554, 2017.

21. Choi HN, Lee JW, Cho YS: Factors associated with turnover intention of public health dental hygienist. J Korean Soc Dent Hyg 11: 343-351, 2011.

22. Ministry of Health and Welfare: 2018 Ministry of Health and Welfare white book. Ministry of Health and Welfare, Sejong, pp.429-435, 2019.

23. Kim JH, Kim HY, Lee SK, Cho YS, Park YD: A survey on working conditions and manpower among dental auxiliary personnel in dental clinics. J Korean Acad Dent Health 32: 540-550, 2008.

24. Moon JS, Choi SB: The effect of career management behavior, organizational support for career development and career outcomes on organizational committment. Korean Bus Educ Rev 27: 431-457, 2012. 